\title{
Tropical urban lichens: observations from Singapore
}

\author{
H.J.M. Sipman ${ }^{1}$
}

\section{Key words}

biodiversity conservation

lichenized mycota

lichens

Singapore

urbanisation effects
Abstract The known lichen diversity of Singapore, 296 species, is comparable with temperate lowland areas, but the taxa involved are different, even at high taxonomic levels: the commonest orders are Arthoniales and Graphidales instead of Lecanorales. Epiphytic species dominate, while saxicolous and terrestrial species are rare. Comparison with pre-2000 records and non-urbanized areas suggests a decrease in forest lichens, cyanophilous macrolichens, and the nitrophilous family Physciaceae.

Published on 30 October 2009

\section{INTRODUCTION}

In recent decades large-scale urbanisation has become a widespread feature in tropical areas, and Singapore is a well-known example. Since urbanized areas worldwide are expanding rapidly and thus becoming more and more important for the conservation of biodiversity, a study of the biota of Singapore seems of particular interest. The city is very suitable for such a study because it has received regular attention from biologists during its development from primary lowland forest with small settlements in c. 1800 to extensive plantations a century later and to the present urbanized area interspersed by parks and forest remnants. Resulting publications dealing with lichenized fungi include, e.g., Krempelhuber (1875), Nylander \& Crombie (1884), Nylander (1891). An evaluation of the literature and fieldwork in 2000 had as result that now 296 lichen species are known from the area (Sipman in press). The present study provides a comparison with the lichen flora of temperate areas and discusses some probable modifications following the urbanisation.

\section{MATERIAL AND METHODS}

The evaluated records originate mainly from fieldwork in 2000 by the author in collaboration with Prof. B.C. Tan, Prof. D.H. Murphy and Mrs. Faridah from the National University of Singapore. On 17 localities 962 samples of lichenized fungi were taken, which provided 1126 records when taking into account mixed specimens and field observations. In addition the published literature was searched for lichen records from Singapore, and relevant specimens were borrowed from the herbaria SING and UPS and the private collections of A. Aptroot, P. Diederich and F. Schumm. For a full list of all records see Sipman (in press). The specimens were investigated in the usual way by stereomicroscope and photomicroscope, and selected specimens were analysed by TLC (Orange et al. 2001) in order to establish their identity.

\section{RESULTS AND DISCUSSION}

The known lichen flora of Singapore appears to comprise the surprisingly high number of 296 species (Sipman in press), in

\footnotetext{
${ }^{1}$ Free University of Berlin, Botanischer Garten und Botanisches Museum, Königin-Luise-Strasse 6-8, D-14195 Berlin, Germany.
}

spite of the fact that lichens are nowhere very conspicuous. The total figure might even exceed 325 , taking into account the remaining unidentified specimens and the probability of overlooked species.

In order to relate this figure to the situation elsewhere in the world, a comparison with similar areas elsewhere in Europe and Asia is made (Table 1). However, similar published inventories appear to be rare, even in the better investigated parts of the temperate zones of the world, and differences in area size, urbanisation and elevational range make the numbers poorly comparable. Two studies in central Sweden (Ornö and Vänge) are available, which concern lowland areas similar to Singapore but of considerably smaller size and less urbanized. They show distinctly higher species numbers. The Norwegian island Vega at the Arctic Circle, more comparable in size but mountainous and hardly urbanized, has a much higher species number, while the Mediterranean island Ikaria, equally mountainous and little urbanized, has only half this number. Two similarly urbanized areas, Berlin and Hong Kong, appear to have similar species numbers in spite of their larger size and thus can be considered to have a poorer lichen flora than Singapore.

The list of commonest species (Table 2) shows that most lichens in Singapore are crustose and that macrolichens (fruticose and foliose lichens) are uncommon: the only such lichen in the list is the foliose Dirinaria picta, which however is very closely applicated to the substrate and hardly recognizable as a macrolichen. The order Lecanorales, dominant in temperate regions, is much less frequent in Singapore; the dominant orders here are Graphidales and Arthoniales. At family level (Table 3) the difference with temperate regions is even more pronounced: of the 6 commonest families in Singapore 4 belong to Graphidales and Arthoniales, while in the temperate locality 4 of the 6 commonest families are Lecanorales.

Another important difference with the lichen flora in temperate regions is the substrate preference (Table 4). While in temperate regions saxicolous species form the majority (as long as sufficient substrate is available), in Singapore it concerns a small group. Also terricolous species are much better represented in cooler climates and in Singapore they are almost absent. On the contrary, in Singapore the far majority of the lichens are epiphytic and its number far exceeds the numbers of epiphytic lichens for all temperate sites listed by Foucard (2004).

Singapore seems particularly suited to monitor changes in the lichen flora, because its lichenological exploration started early. 
Table 1 Species numbers of lichenized fungi in selected areas.

\begin{tabular}{lcccl}
\hline Locality & Size $\left(\mathrm{km}^{2}\right)$ & Summit $(\mathrm{m})$ & Species $\mathrm{nr}$. & Source \\
\hline Sweden, Ornö island & 48 & c. 40 & 441 & Degelius 1942 \\
Sweden, Vänge & 30 & c. 50 & 433 & Foucard 2004 \\
Norway, Vega island & 163 & 797 & $668+$ & Degelius 1982 \\
Greece, Ikaria island & 255 & 910 & c. 350 & Sipman unpublished \\
Singapore & 693 & 166 & $\mathbf{2 9 9}$ & present study \\
Berlin & 892 & 115 & 290 & Sipman \& Aptroot 2008 \\
Hong Kong & 1098 & 958 & 308 & Aptroot \& Sipman 2001 \\
\hline
\end{tabular}

Table 2 The 31 commonest lichen species of Singapore, with order and number of reports. For pictures see http://www.bgbm.fu-berlin.de/sipman/ Zschackia/Singa/genuslist.htm.

\begin{tabular}{|c|c|c|}
\hline Species & Order & Number of reports \\
\hline Arthonia catenulata & Arthoniales & 47 \\
\hline Dirinaria picta & Lecanorales & 46 \\
\hline Phaeographis intricans & Graphidales & 35 \\
\hline Pyrenula ochraceoflava & Pyrenulales & 33 \\
\hline Graphis caesiella & Graphidales & 32 \\
\hline Ocellularia crocea & Graphidales & 28 \\
\hline Ocellularia papillata & Graphidales & 22 \\
\hline Graphis hiascens & Graphidales & 20 \\
\hline Phaeographis caesioradians & Graphidales & 17 \\
\hline Chrysothrix xanthina & Arthoniales & 15 \\
\hline Cresponea flava & Arthoniales & 14 \\
\hline Trypethelium variolosum & Pyrenulales & 13 \\
\hline Lepraria usnica & Lecanorales & 13 \\
\hline Cryptothecia scripta & Arthoniales & 13 \\
\hline Diorygma rufopruinosum & Graphidales & 13 \\
\hline Amandinea efflorescens & Lecanorales & 12 \\
\hline Anisomeridium throwerae & Pyrenulales & 12 \\
\hline Lecanora helva & Lecanorales & 12 \\
\hline Porina tetracerae & Trichotheliales & 12 \\
\hline Trypethelium tropicum & Pyrenulales & 12 \\
\hline Mycoporum eschweileri & Pyrenulales & 10 \\
\hline Pyrrhospora quernea & Lecanorales & 10 \\
\hline Trypethelium eluteriae & Pyrenulales & 10 \\
\hline Trypethelium epileucodes & Pyrenulales & 10 \\
\hline Bactrospora myriadea & Arthoniales & 9 \\
\hline Cryptothecia lunulata & Arthoniales & 9 \\
\hline Sarcographina glyphiza & Graphidales & 9 \\
\hline Cryptothecia granularis & Arthoniales & 8 \\
\hline Graphis glaucescens & Graphidales & 8 \\
\hline Myriotrema subconforme & Graphidales & 8 \\
\hline Trypethelium platystomum & Pyrenulales & 8 \\
\hline
\end{tabular}

The species list (Sipman in press) contains 137 taxa which were observed before 2000. Of these 86 were not refound in 2000. This seems a surprisingly high number in view of the fact that so many additional species were found and the 2000 inventory seems reasonably complete. The following explanations can be postulated for their absence, depending on the date of observation:

1. Species reported before 1900 and not refound afterwards (47 taxa) concern most probably obligate forest species, which disappeared after logging of the forest. Evident cases of species, which were reported in the past from Singapore and are nowadays found only in primary forest relics away from Singapore include, e.g., Ocellularia triglyphica and Thelotrema isidiophorum (specimens available from Gunung Pulai in Johor, Malaysia). However, in some cases the reports concern poorly-known species of uncertain status, which may eventually appear to be synonyms or misapplied names. The status of such reports can only be ascertained by a re-examination of vouchers, if any are left.

2. Species reported after 1900 (39 taxa) are usually without much doubt about their identity. It may concern uncommon species which have been missed by accident. However, it concerns usually conspicuous macrolichens which have
Table 3 Comparison between the lichen flora of Singapore and Berlin (after Sipman \& Aptroot 2008). Shown are species number and 6 commonest families.

\begin{tabular}{lrlr}
\hline Singapore: 299 & \multicolumn{3}{l}{ Berlin: 290} \\
\hline Graphidaceae & $11 \%$ & Cladoniaceae & $10 \%$ \\
Thelotremataceae & $9 \%$ & Lecanoraceae & $9 \%$ \\
Roccellaceae & $7 \%$ & Parmeliaceae & $8 \%$ \\
Arthoniaceae & $8 \%$ & Teloschistaceae & $7 \%$ \\
Trichotheliaceae & $4 \%$ & Verrucariaceae & $6 \%$ \\
Physciaceae & $3 \%$ & Physciaceae & $5 \%$ \\
\hline
\end{tabular}

Table 4 Substrate preference of the lichen flora of Singapore and Berlin (after Sipman \& Aptroot 2008).

\begin{tabular}{lrr}
\hline & Singapore & Berlin \\
\hline Saxicolous & $7 \%$ & $41 \%$ \\
Epiphytic & $92 \%$ & $37 \%$ \\
Terrestric & $1 \%$ & $18 \%$ \\
\hline
\end{tabular}

Table 5 Comparison of the dominant lichen families in Singapore, a heavily industrialized conurbation, and Madang (Papua New Guinea), an unindustrialized town with similar climate.

\begin{tabular}{lrlr}
\hline Singapore & \multicolumn{3}{l}{ Madang } \\
\hline Graphidaceae & $16 \%$ & Graphidaceae & $22 \%$ \\
Thelotremataceae & $12 \%$ & Physciaceae & $17 \%$ \\
Roccellaceae & $10 \%$ & Pyrenulaceae & $15 \%$ \\
Arthoniaceae & $8 \%$ & Roccellaceae & $8 \%$ \\
Trichotheliaceae & $5 \%$ & Arthoniaceae & $5 \%$ \\
Physciaceae & $5 \%$ & Trypetheliaceae & $5 \%$ \\
\hline
\end{tabular}

been observed more than once in the past and are unlikely to be overlooked. A decrease is the most likely explanation for their current scarcity: Dirinaria spp., Collema spp., Leptogium spp., Physma byrsaeum. This group includes a particularly conspicuous and easily collectable group of foliose, often gelatinous, epiphytic lichens with cyanobacteria as photobiont ('cyanophilous' species), which are well represented in the herbarium collections but scarcely found in 2000. Such lichens are known from Europe as particularly sensitive to air contamination, and their decrease in Singapore might be an indication for air quality changes. The equally strong evidence for a decrease in Dirinaria spp. (cf. Awasthi 1975) is less easily understandable because they belong to the family Physciaceae, a group which generally profits from an increase in fixed nitrogen as often observed in urbanized areas. However, also Table 5 suggests a reduction in Physciaceae in Singapore.

In a discussion on changes in the lichen flora of Singapore, the deforestation is probably the most important factor to be addressed. From temperate forests it is well-known that a considerable number of lichen species cannot stand the disturbance of clear-felling (e.g., Coppins \& Coppins 2006), and there seems no reason why this would be different in the 
tropics. Unfortunately, the number of lichen species reported from Singapore before c. 1900, when the primary forests were probably still readily available and logging would have made the sampling of lichens easy, is very limited. Certainly it has not been very representative, because many additional forest lichens have been found in secondary forest (e.g., loc. 10, 11, $12 \mathrm{cf}$. Sipman in press) in the year 2000, which most probably have been present also before. How many lichen species might have grown in the primary forest cover of the area is difficult to estimate, because there is very little information about the lichen flora of primary forests anywhere in the humid tropics of Southeast Asia. Aptroot (1997) indicates 500 species for lowland primary forest in northern Papua New Guinea and there seems no reason why this figure would be very different in Singapore. If so, several hundred lichen species may have disappeared from Singapore due to the clearing of the primary forest.

Despite the significance of the primary state of forests for lichens, visits in 2000 to the primary forest remnants in the Botanical Garden and on Bukit Timah revealed a poor lichen flora. Lichens were absent from most of the trunks and restricted to tree bases and sheltered valleys, where they were often poorly developed. A freshly fallen, large tree allowed a detailed inspection of the crown with only one species on a sheltered part of the trunk (\# 46379, Ocellularia interponenda) as result. This differs much from the situation in primary tropical forests away from industrial areas, where the crowns of most trees harbour dozens of species, cf. Komposch \& Hafellner (1999), and resembles the situation in temperate areas with high sulphur dioxide pollution, where tree crowns are devoid of lichens. Evidently the primary forest remnants in Singapore have not served as refuges for the lichen diversity of the primary forest.

To assess possible changes in the non-forest lichen flora, unpublished data from the small, unindustrialized town Madang on the north-coast of Papua New Guinea have been used (Table 5). They show a lower representation of Thelotremataceae in Madang, which can be explained because in the inventory of Singapore forest remnants were included. For the lower representation of Physciaceae and Pyrenulaceae in Singapore there seems no habitat-dependant explanation and it may reflect air quality changes related to urbanization.

Acknowledgements The very generous support by Prof. B.C. Tan (NUS), who kindly invited the author for the 2000 inventory, arranged many aspects of the inventory, including all finances, and provided research facilities in his lab at NUS, is highly appreciated. For loan of specimens A. Aptroot, P. Diederich, F. Schumm and the curators of SING and UPS are gratefully acknowledged. Prof. C.H. Murphy and Faridah kindly provided fieldwork support and pleasant company. The National Parks Board and Singapore Botanic Gardens helpfully provided the necessary permits for the fieldwork and the Raffles Museum for Biodiversity Research enabled the project by financial support.

\section{REFERENCES}

Aptroot A. 1997. Lichen biodiversity in Papua New Guinea, with the report of 173 species on one tree. In: Türk R, Zorer R (eds), Progress and problems in lichenology in the nineties. Bibliotheca Lichenologica 68: 203-213. Cramer, Berlin, Stuttgart.

Aptroot A, Sipman HJM. 2001. New Hong Kong lichens, ascomycetes and lichenicolous fungi. Journal of the Hattori Botanical Laboratory 91: 317343.

Awasthi DD. 1975. A monograph of the lichen genus Dirinaria. Bibliotheca Lichenologica 2. Cramer, Vaduz.

Coppins BJ, Coppins AM. 2006. The lichens of the Scottish native pinewoods. Forestry 79, 3: 249-259

Degelius G. 1942. Die Flechten der Insel Ornö. Svensk Botanisk Tidskrift Utgifven af Svenska Botaniska Foreningen 36: 9-48.

Degelius G. 1982. The lichen flora of the island of Vega in Nordland, northern Norway. Acta Regiae Societatis Scientiarum et Litterarum Gothoburgensis, Botanica 2: 1-127.

Foucard T. 2004. A lichen inventory in a $30 \mathrm{~km}^{2}$ large area in central Uppland, Sweden. In: Thor G, Nordin A, Hedberg I (eds), Contributions to lichen taxonomy and biogeography dedicated to Leif Tibell. Symbolae Botanicae Upsalienses 34, 1: 53-61. Uppsala.

Komposch H, Hafellner J. 1999. List of lichenized fungi so far observed in the tropical lowland rain forest plot Surumoni (Venezuela, Estado Amazonas). Fritschiana 19: 1-10.

Krempelhuber A. 1875. Lichenes quos legit O. Beccari in insulis Borneo et Singapore annis 1866 et 1867 . Nuovo Giornale Botanico Italiano 7, 1: 5-67, pl. 1-2.

Nylander W. 1891. Sertum lichenaeae tropicae e Labuan et Singapore. Paris. Nylander W, Crombie JM. 1884. On a collection of exotic lichens made in Eastern Asia by the late Dr. A.C. Maingay. Journal of the Linnean Society, Botany 20: 48-69.

Orange A, James PW, White FJ. 2001. Microchemical methods for the identification of lichens. British Lichen Society, London.

Sipman HJM. 2003. New species of Cryptothecia, Lepraria, and Ocellularia (lichenized Ascomycetes) from Singapore. In: Jensen M (ed), Lichenological contributions in honour of G.B. Feige. Bibliotheca Lichenologica 86: 177-184. Cramer, Berlin, Stuttgart.

Sipman HJM. In press. A conspectus of the lichenized fungi of Singapore. Gardens' Bulletin Singapore.

Sipman H, Aptroot A. 2008. Beitrag zur Kenntnis der Flechtenflora des Landes Berlin. Verhandlungen des Botanischen Vereins von Berlin und Brandenburg 140: 101-117. 
